\title{
N-cym Protein
}

National Cancer Institute

\section{Source}

National Cancer Institute. N-cym Protein. NCI Thesaurus. Code C33964.

$\mathrm{N}$-cym protein (109 aa, $12 \mathrm{kDa}$ ) is encoded by the human MYCNOS gene. This protein may play a role in embryonic development. 